\section{On the Authorship of Babina (Ampbibia: Ranidae)}

\section{HIDETOSHI OTA ${ }^{1 *}$ AND MASAFUMI MATSUI $^{2}$}

1 Tropical Biosphere Research Center, University of the Ryukyus, Nishihara, Okinawa 903-0213, JAPAN

2 Graduate School of Human and Environmental Studies, Kyoto University, Yoshida-Nihonmatsu-cho, Sakyo-ku, Kyoto 606-8501, JAPAN

Abstract: The genus-group name Babina, originally proposed as a full genus for Rana holsti (type species) and $R$. subaspera, is usually attributed to "Van Denburgh, 1912". However, it is obvious from the chronological order of publication of relevant papers that the authorship of Babina should be "Thompson, 1912", not "Van Denburgh, 1912".

Key words: Babina; Ranidae, Anura; Nomenclature; Authorship; Priority

The genus-group name Babina was first published in 1912 by two different authors, Thompson (1912a) and Van Denburgh (1912a). In both of these papers, the name was given to a new full genus described to accommodate two endemic frogs of the central Ryukyus, Rana holsti Boulenger, 1892, and R. subaspera Barbour, 1908, with the former being the type species. Also, both Thompson (1912a) and Van Denburgh (1912a) highlighted a sharp, spine-like metacarpal on the inner side of the first finger in these two species as the prominent character distinguishing Babina from other ranid genera.

Van Denburgh published a more detailed description of the genus, without referring to Thompson's (1912a) description, in his famous work on the East Asian herpeto-

* Corresponding author. Tel: + 81-98-895-8937; Fax: +81-98-895-8966; E-mail address; ota@sci.uryukyu.ac.jp fauna published later in the same year (Van Denburgh, 1912b). Probably because both of the preceding descriptions were privately published by the respective authors and thus suffered limited availability, Van Denburgh (1912b) seems to have been regarded as the only source of information on the original description of Babina by most subsequent authors. Some of them (e.g., Okada [1930], p. 154) even erroneously referred to Van Denburgh (1912b) as the original description of the genus, although it was unequivocally stated on Van Denburgh's (1912b) second page that a number of his new taxa (including Babina) were originally described in Van Denburgh (1912a).

Of the subsequent authors, some considered Babina as invalid (Inger, 1947; Dubois, 1981), others continued to use the name as a valid full genus (Okada, 1930, 1966), whereas most recent authors regard Babina as a subgenus of Rana (Nakamura and Uéno, 1963; Kuramoto, 1972; Matsui and Utsunomiya, 1983; Frost, 1985; Maeda and Matsui, 1989; Dubois, 1992; Duellman, 1993). In any event, authorship of this genus-group name has invariably been given as "Van Denburgh, 1912" (e.g., Okada, 1930, 1966; Inger, 1947; Nakamura and Uéno, 1963; Dubois, 1992; Duellman, 1993).

In 1912, Thompson and Van Denburgh separately described a number of East Asian amphibians and reptiles on the basis of the same series of specimens (and sometimes even on the basis of exactly identical holotype specimens) in rivalry with each other (Zhao and Adler, 1993: p. 32), and this resulted in a "most regrettable tangle of names" (Barbour, 1917; Nakamura and Uéno, 1963; Zhao and Adler, 1993). Nakamura and Uéno (1963) referred to this confusing situation with an example of the authorship of Hyla hallowellii, a species described by both Thompson (1912b) and Van Denburgh (1912a). While severely criticizing Thompson's actions, Nakamura and Uéno (1963) argued that the name, usually given as "Hyla hallowellii Van Denburgh, 1912" to 
that date (e.g., Okada, 1930; Inger, 1947), should be attributed to "Thompson, 1912", recognizing that Thompson (1912b) had preceded Van Denburgh (1912a) by approximately one month. Nakamura and Uéno (1963), nevertheless, continued to regard "Van Denburgh, 1912" as the author of Babina, although Thompson (1912a: Herpetological notices 1) should have preceded Thompson (1912b: Herpetological notices 2) in publication date.

Based on the date printed in each of the relevant papers, Zhao and Adler (1993) confirmed the chronological order of their publications as Thompson (1912a: on 15 June), Thompson (1912b: 28 June), Van Denburgh (1912a: on 29 July), and Van Denburgh (1912b: on 16 December). It is thus obvious from the principle of priority of the International Code of Zoological Nomenclature (2000) that Thompson (1912a) should be regarded as the author of the original description of Babina. Thus, the authorship of this genus-group name should be "Thompson, 1912", not "Van Denburgh, 1912".

\section{ACKNOWLEDGMENTS}

We thank K. Adler and R. I. Crombie for the provision of pertinent literature.

\section{LITERATURE CITED}

BARBOUR, T. 1917. A most regretable [sic] tangle of names. Occ. Pap. Mus. Zool. Univ. Michigan (44): 1-9.

DuBoIS, A. 1981. Liste des genres et sous-genres nominaux de Ranoidea (Amphibiens Anoures) du monde, avec identification de leurs espècestypes: conséquences nomenclaturales. Monit. Zool. Ital., New Ser. 15 (suppl.): 225-284.

DuboIs, A. 1992. Notes sur la classification des Ranidae (Amphibiens Anoures). Bull. Mens. Soc. Linn. Lyon 61(10): 305-352.

Duellman, W. E. 1993. Amphibian species of the world: additions and corrections. Univ. Kansas Mus. Nat. Hist. Spec. Publ. (21): 1-
372.

Frost, D. (ed.) 1985. Amphibian Species of the World: A Taxonomic and Geographical Reference. Allen Press, Lawrence. 732 p.

INGER, R. F. 1947. Preliminary survey of the amphibians of the Riukiu Islands. Fieldiana: Zool. 32(5): 297-352.

INTERNATIONAL CODE OF ZOOLOGICAL NOMENCLATURE. Fourth Edition. 1999. International Trust for Zoological Nomenclature, The Natural History Museum, London. I-xxix + 306 p.

KURAMOTO, M. 1972. Karyotypes of the six species of frogs (genus Rana) endemic to the Ryukyu Islands. Caryologia 25(4): 547-559.

MAedA, N. AND M. MATSUi. 1989. Frogs and Toads of Japan. Bun-ichi Sogo Shuppan, Tokyo. 207 p.

MATSUI, M. AND T. UTSUNOMIYA. 1983. Mating call characteristics of the frogs of the subgenus Babina with reference to their relationship with Rana adenopleura. J. Herpetol. 17(1): 32-37.

NAKAMURA, K. AND S.-I. UÉNO. 1963. Japanese Reptiles and Amphibians in Colour. Hoikusha, Osaka. 214 p. (in Japanese)

OKADA, Y. 1930. A Monograph of Japanese Tail-less Batrachians. Iwanami-shoten, Tokyo. 234 p. +27 pls. (in Japanese)

OKADA, Y. 1966. Fauna Japonica: Anura (Amphibia). Tokyo Electronic Engineering College Press, Tokyo. $12+234$ p.

THOMPSON, J. C. 1912a. Herpetological Notices No. 1. Prodrome of a Description of a New Genus of Ranidae from the Loo Choo Islands. Privately published by the author, San Francisco. 3 p.

THOMPSON, J. C. 1912b. Herpetological Notices No. 2. Prodrome of Descriptions of New Species of Reptilia and Batrachia from the Far East. Privately published by the author, San Francisco. 3 p.

VAN DENBURgh, J. 1912a. Advance Diagnoses of New Reptiles and Amphibians from the Loo Choo Islands and Formosa. Privately published by the author, San Francisco. 8 p.

VAN Denburgh, J. 1912b. Concerning certain species of reptiles and amphibians from China, Japan, the Loo Choo Islands, and 
Formosa. Proc. California Acad. Sci. Ser. 4, 3: $187-258$.

ZHAO, E. AND K. ADLER. 1993. Herpetology of
China. Society for the Study of Amphibians and Reptiles, Oxford, Ohio. 522 p.

Accepted: 12 May 2002 